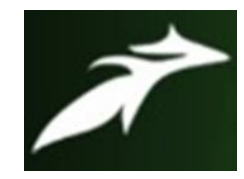

Mittu Katoch et al, International Journal of Advances in Agricultural Science and Technology, Vol.8 Issue.6, June-2021, pg. 10-26

ISSN: 2348-1358

Impact Factor: 6.057

NAAS Rating: 3.77

\title{
Linseed and Its Basic Composition
}

\author{
Mittu Katoch*; Narender Singh Bhatia \\ M.Sc Botany, M.Sc Biotechnology \\ *Corresponding author email: mitukatoch.katoch@gmail.com \\ DOI: 10.47856/ijaast.2021.v08i6.002
}

\begin{abstract}
The archaeological evidence of flax cultivation dates back to $>6000 \mathrm{BC}$ and it is considered as one of the oldest and most useful crops. Components of flax have diverse uses. Cultivar development of flax is currently focused on enhancing the oil content and nutritional value to meet the demand of nutraceutical market supply, as an alternate source of fish oil, a rich source of eicosapentaenoic acid (EPA, C20:5) and docosahexaenoic acid (DHA, C22:6). Growing awareness about the role of diet and quest for human wellness has fuelled interest in 'Functional foods' and functional attributes of many traditional foods are being reinvented. Flaxseed is cultivated in many parts of world for fiber, oil as well as for medicinal purposes and also as nutritional product. Flax continues to surge forward in its recognition as a functional food. It is the richest known source of alpha-linolenic acid, the phytoestrogen, lignans, as well as being a good source of soluble fiber. Flax is also very important fibrous bast plant, both for valuable textile fibres and composites applications and for bioactive compounds used in folk medicine, nutraceuticals and functional food. Flax seeds are rich in valuable fatty acids, amino-acids, phytoestrogens, cyclolinopeptides, lecithin, waxes, lignin, pectin, mucilage, etc. $\omega-3$ and $\omega-6$ polyunsaturated fatty acids (PUFA) are effective preventing cardiovascular and heart diseases. The flax seed has been shown to possess significant antioxidant and anti-inflammatory functions. In this review, composition, essential fatty acids,omega-3 fatty acid, alpha linolienic acid, proteins, vitamins and minerals, lignans, dietary fiber and uses of flaxseed are discussed.
\end{abstract}

Keywords: Omega-3 Fatty Acid, Alpha Linolienic Acid, Proteins, Vitamins and Minerals, Lignans, Dietary Fiber.

*Corresponding Author: Mittu Katoch. Email id- mitukatoch.katoch@gmail.com 


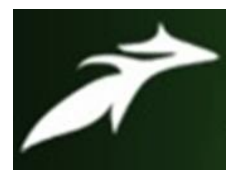

Mittu Katoch et al, International Journal of Advances in Agricultural Science and Technology, Vol.8 Issue.6, June-2021, pg. 10-26

ISSN: 2348-1358

Impact Factor: 6.057

NAAS Rating: 3.77

\section{Introduction}

In the relationship between diet, health and well-being, functional foods play an outstanding role. Many definitions exist worldwide for functional foods, but there is no official or commonly accepted definition (Kalra EK. 2003.). The European Commission's Concerted Action on Functional Food Science in Europe (FuFoSE), defined that a food product can only be considered functional if together with the basic nutritional impact it has beneficial effects on one or more functions of the human organism thus either improving the general and physical conditions or/and decreasing the risk of the evolution of diseases (Doyon $\mathrm{M}$ and Labrecque $\mathrm{J}$. 2008). In the last years, thanks to the evolution of scientific research, flaxseed is emerging as an important functional food ingredient. Flaxseed is the seed from the flax plant, an annual herb, which is a member of the Linaceae family. It thrives in deep moist soils rich in sand, silt, and clay. The specie is native to the region extending from the eastern Mediterranean, through Western Asia and the Middle East, to India. The Latin name of flaxseed (Linum usitatissimum L.) means "very useful", and it has two basic varieties: brown and yellow or golden (also known as golden linseeds) (Daun JKetal., 2003) Flax (Linum usitatissimum L.) is a multi-purpose crop. Its' seeds containing about 36 to $40 \%$ of oil, have long been used in human and animal diets and in industry as a source of oil and as the basic component or additive of various paints or polymers. Recently there has been a growing interest in the probiotic properties of flax and in its beneficial effects on coronary heart disease, some kinds of cancer and neurological and hormonal disorders (Huang and Milles, 1996; Huang and Ziboh, 2001; Simopoulos, 2002). Globally, Flaxseed is grown as either oil crop or a fiber crop with fiber linen derived from the stem of fiber varieties and oil from the seed of linseed varieties (Diederichsen et al., 2003; Vaisey-Genser et al., 2003). The whole flaxseed is flat and oval with pointed tips and contains a seed coat or true hull (also called testa), a thin endosperm, two embryos and an embryo axis (Morris DH,2007). Every part of the linseed plant is utilized commercially, either directly or after processing. The shell yields good quality fiber having high mechanical properties and low density instead the seed provides oil rich in omega-3, digestible proteins and lignans; it is also use to manufacture paints, varnishes, linoleum, oilcloths, printing inks, soaps and numerous other products.

Thanks to its composition, flaxseed is emerging as an important functional food ingredient because provides oil rich in omega-3, digestible proteins, and lignans. In addition to being one of the richest sources of $\alpha$-linolenic acid oil and lignans, flaxseed is an essential source of high quality protein and soluble fiber and has considerable potential as a source of phenolic compounds (Oomah DB, 2001)( Pengilly NL,2003). Flaxseed mucilage has gained momentum due to its superb health benefits and potential functional properties (Susheelamma 1987; Mazza and Biliaderis 1989).

\section{Composition}

Flaxseeds have a hard shell that is smooth and shiny and the color ranges from deep amber to reddish brown depending upon whether the flax is of the golden or brown variety. The envelope 


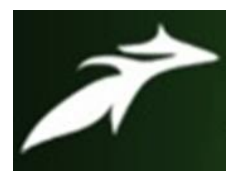

Mittu Katoch et al, International Journal of Advances in Agricultural Science and Technology, Vol.8 Issue.6, June-2021, pg. 10-26

ISSN: 2348-1358

Impact Factor: 6.057

NAAS Rating: 3.77

or testa of the seed contains about $15 \%$ of mucilage. Flaxseed is rich in fat, protein and dietary fibre. Flaxseed is rich in fat, protein and dietary fibre. The composition of flaxseed can vary with genetics, growing environment and method of seed processing (Daun JK et al., 2003), An analysis of brown Canadian flaxseed averaged $41 \%$ fat, $20 \%$ protein, $28 \%$ total dietary fibre, $7.7 \%$ moisture and $3.4 \%$ ash which is the mineral-rich residue left after samples are burned (Morris, 2003). The protein content of the seed decreases as the oil content increases (Daun JK and DeClercq DR, 1994). It is well known that flax seeds are a source of high content of polyunsaturated fatty acids (Pradhan R et al., 2010). Among the functional foods, flaxseed has emerged as a potential functional food being good source of alpha-linolenic acid, lignans, high quality protein, soluble fiber and phenolic compounds (Oomah 2001).

\section{Fatty acids}

Fatty acids are termed as essential because both they are required by the body but body cannot synthesize them, therefore need to be supplied in the diet. Human body lacks the enzymeswhich are required for the synthesis of these essential fatty acids (de Lorgeril et al. 2001).Flaxseed is rich in the essential omega-3 fatty acid, alpha linolenic acid. The omega-3 fatty acids have biologic effects that make them useful in preventing and managing chronic conditions such as type 2 diabetes, kidney disease, rheumatoid arthritis, high blood pressure, coronary heart disease, stroke, Alzheimer disease, alcoholism and certain types of cancers (Das UN, 2006)

Fatty acids content of Flaxseed oil

\begin{tabular}{|l|l|}
\hline Parameter & Percentage (\%) \\
\hline Saturatedfat & 9.0 \\
\hline Monounsaturatedfat & 18.0 \\
\hline Linoleicacid(omega-6fattyacid) & 16.0 \\
\hline$\alpha$-Linolenic acid (omega-3 fatty acid) & 57.0 \\
\hline
\end{tabular}

(Source: Morris, D. H. 2003. Flax: A health and nutrition primer. p.11. Winnipeg: Flax Council of Canada)

\section{Alpha-linolenic acid (Omega-3 fatty acid)}

Alpha-linolenic acid is the main functional component of flaxseed. It serves as an exclusive source of omega-3 fatty acid in the vegetarian diets (Riediger et al. 2009). It is rich in both the essential fatty acids - alpha-linolenic acid (ALA), and linolenic acid (LA). There are two groups of omega fats: omega-3 and omega-6 fatty acids. Linolenic acid, eicosapentaenoic acid (EPA) and docosahexanoic acid (DHA) are three types of omega-3 fatty acids and are nutritionally important. All three fatty acids have been shown to reduce the risk of cardiovascular disease (Hurteau, 2004). ALA and Linoleic acid constitutes 57\% and $16.0 \%$ of total fatty acids respectively in flax making the richest source of ALA. ALA from flaxseed exerts positive effect on blood lipids. It was found to be as effective as oleic acid $(18: 2 \eta-6)$ and linoleic acid $(18: 2 \eta-6)$ 


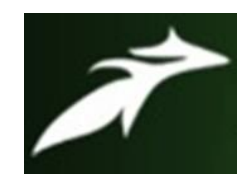

Mittu Katoch et al, International Journal of Advances in Agricultural Science and Technology, Vol.8 Issue.6, June-2021, pg. 10-26

ISSN: 2348-1358

Impact Factor: 6.057

NAAS Rating: 3.77

in the reduction of plasma total cholesterol, low density lipoprotein cholesterol and very low density lipoprotein cholesterol in 20-34 years old healthy men (Chan et al., 1993). a typical diet has an n-6 to n-3 fatty acid ratio well beyond 10:1; thus, flaxseed can be a valuable lipid source to improve the n-6 to n-3 fatty acid ratio due to the high n-3 content of flaxseed oil. Ground flaxseed is high in omega-3 fatty acids which have been shown to reduce hypertension, cholesterol and triglyceride level (Oomah and Maza, 1998). ALA, being the essential fatty acid, requirement can be fulfilled by intake of flaxseed products (Morris, 2004).

\section{Protein}

The protein content in flaxseed has been reported to between $10.5 \%$ and $31 \%$ (Oomah and Mazza, 1993). The amino acid pattern of flax protein is similar to that of soybean protein, which is viewed as one of the most nutritious of the plant proteins. There appears to be little difference in the amino acid content of the protein from two flax varieties shown in Table 2. Flax is glutenfree. The specific agent in gluten that causes a condition known as 'celiac disease' is gliadin, which is rich in the amino acids proline and glutamine. (Aubrecht E et al., 1998). The proximate protein content of dehulled and defatted flaxseed varied considerably depending upon cultivar growth location and seed processing. Hull fraction contains lower protein levels and that dehulling increases protein level of flaxseed protein level from $19.2 \%$ to $21.8 \%$ (Oomah and Mazza, 1997). Albumin and globulin type proteins are the major proteins in flaxseed. Flaxseed albumin comprised 20\% of meal protein (Madhusudhan and Singh, 1983). Oomah and Mazza (1995) compared the nutritional value of flaxseed meal with soybean meal and concluded that net protein utilization and protein efficiency ratio of flaxseed meal were slightly lower than soybean meal with the exception of protein scores, which were high in flaxseed meal. The BV of flaxseed protein was similar to those of soybean protein

\section{Fibre}

Diets rich in dietary fibre may help reduce the risk of heart disease, diabetes, colorectal cancer, obesity and inflammation (Morris, 2003). Total fibre is the sum of dietary fibre and functional fibre. Functional fibre consists of nondigestible carbohydrates that have been extracted from plants, purified and added to foods and other products. Dietary fibre and functional fibre are not digested and absorbed by the human small intestine and, therefore, pass relatively intact into the large intestine (Institute of Medicine (2002). Dietary fiber is a communal word used to describe a variety of plant substances that are not easily digested by the enzymes responsible for digestion in humans (Eastwood and Passmore, 1983). Total dietary fiber content of flaxseed is given in Table 1

Table 1. Dietary Fiber content of flaxseed

\begin{tabular}{|l|l|}
\hline Dietary Fiber component & Gram per 100 gram of flaxseed \\
\hline TotalDietary & 40 \\
\hline
\end{tabular}




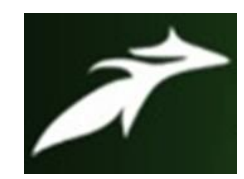

Mittu Katoch et al, International Journal of Advances in Agricultural Science and Technology, Vol.8 Issue.6, June-2021, pg. 10-26

ISSN: 2348-1358

Impact Factor: 6.057

NAAS Rating: 3.77

\begin{tabular}{|l|l|}
\hline Solublefiber & 10 \\
\hline Insolublefiber & 30 \\
\hline
\end{tabular}

Source: Carter, J.F.1993. Potential of flaxseed and flaxseed oil in baked goods and other products in human nutrition. Cereal Foods World 38 (10): 753-759)

Insoluble fiber consists of cellulose, hemicellulose and lignin (Morris 2007; Oomah and Mazza 1993). Most of the soluble fiber of flaxseed appears to be the mucilage of seed coat. It makes up 7-10\% of seed weight (Mazza and Biliaderis 1989). High amount of dietary fiber adds bulk to waste products in the gut and increases bile movement in the gastrointestinal movement. It exhibits natural laxative effect of dietary fiber. Flaxseed mucilage associated with hull of flaxseed is a gum like material composed of acidic and neutral polysaccharides. The neutral fraction of flaxseed contains xylose $(62.8 \%)$ where as the acidic fraction of flaxseed is comprised mainly of rhamnose (54.5\%) followed by galactose (23.4\%) (Cui et al., 1994).

Cellulose The main structural material of plant cell walls.

\section{Mucilage gums}

Soluble fiber in the form of mucilaginous material consists mainly of water soluble polysaccharides; its recovery and purity vary with the extraction conditions. The water binding capacity of flaxseed mucilage is reported to be about 1600-3000 g of water/ $100 \mathrm{~g}$ of solids. High water binding capacity of flaxseed is attributed due to the presence of polysaccharides in the seed coat (Fedenuik and Biliaderis 1994; Wanasundara and Shahidi 1997). Flaxseed mucilage associated with hull of flaxseed is a gum like material composed of acidic and neutral polysaccharides. The neutral fraction of flaxseed contains xylose $(62.8 \%)$ where as the acidic fraction of flaxseed is comprised mainly of rhamnose (54.5\%) followed by galactose (23.4\%) (Cui et al., 1994).Flax mucilage consists of three distinct types of arabinoxylans which form large aggregates in solution and contribute to its gel qualities (Warrand $\mathrm{J}$ et al., 1876.) Mucilage gums extracted from flax seeds are added to laxatives and cough syrups (BeMiller JN et al., 1993). Mucilage of flaxseed consists of acidic and neutral polysaccharides. The neutral fraction constitutes L-arabinose, Dxylose and D-galactose and arabinoxylan and acidic fraction contains L-rhamnose, L-fucose, L-galactose and Dgalactouronic acid (Wanasundara and Shahidi 1997). Functionally, these polysaccharides possess similar properties to guar gum (Wanasundara and Shahidi 1994; Tarpila et al. 2005). The mucilage can be extracted by water and exhibit good foam-stability properties (Susheelamma 1987).

\section{Lignin}

Lignans are phytoestrogens, which are abundantly available in fiber rich plants, cereals (wheat, barley, and oats), legumes (bean, lentil, soybean), vegetables (broccoli, garlic, asparagus, carrots) fruits, berries, tea and alcoholic beverages. Flaxseed contains about 75-800 times more lignans 


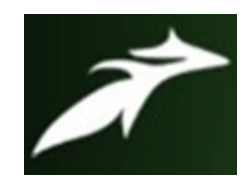

Mittu Katoch et al, International Journal of Advances in Agricultural Science and Technology,

Vol.8 Issue.6, June-2021, pg. 10-26

ISSN: 2348-1358

Impact Factor: 6.057

NAAS Rating: 3.77

than cereal grains, legumes, fruits and vegetables (Mazur et al. 2000;Meagher and Beecher 2000; Murphy and Hendrich 2002; Hosseinian and Beta 2009).

It is a highly-branched fibre found within the cell walls of woody plants. Lignins are related to a similar-sounding compound-lignans. Both are part of plant cell walls and are associated with cell wall carbohydrates. Lignins contribute to the strength and rigidity of the cell walls. Lignans are phytochemicals whose role in human nutrition, particularly cancer prevention, is being studied actively (Safe S and Papineni S, 2006). Flaxseed is the richest source of plant lignans (Thompson et al., 1991). Secoisolariciresinol diglucoside (SDG) is the predominant lignan in flaxseed with minor amount of pinoresinol and matairesinol (MAT) (Meagher et al., 1999; Thompson et al., 1991). SDG was found $2653 \mathrm{mg} / 100 \mathrm{~g}$ of non defatted flaxseed extract (Hall and Shultz, 2001). Secoisolariciresinol (SECO) is produced by acid hydrolysis of secoisolariciresinol diglycoside. Secoisolariciresinol diglycoside existing bound form as a complex of five secoisolariciresinol diglycoside residues held together by four HMGA (3-hydroxy-3-methylglutaric acid) residues in the outer layers of the seed (Kamal-Eldin et al. 2001; Raffaelli et al. 2002; Muir 2006). Structures of the flaxseed lignans complied from different sources (Toure and Xueming 2010; Meagher et al. 1999) are presented in Fig. 1.

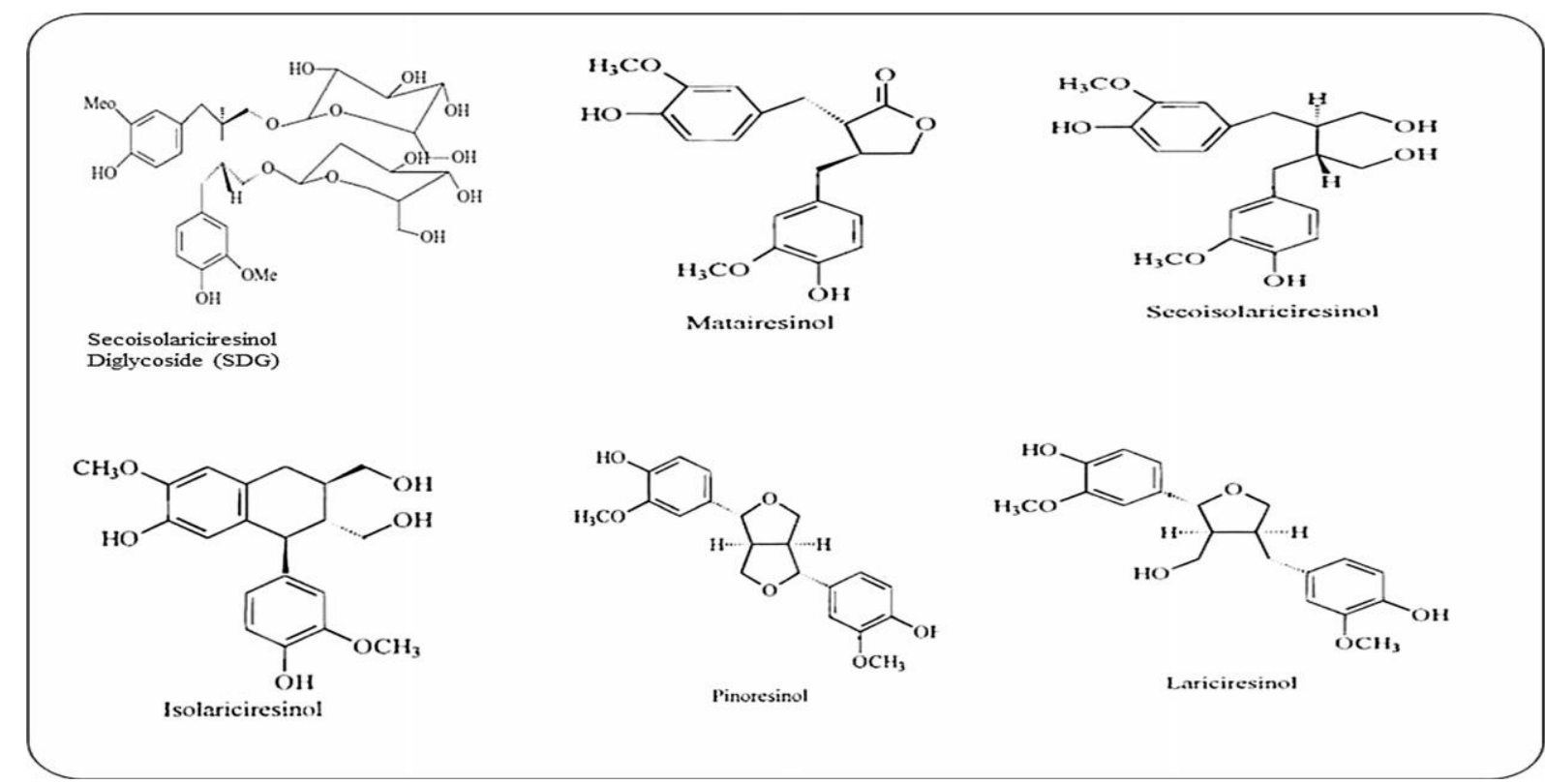

Source: Flaxseed - a potential functional food Source, Priyanka Kajla, Alka Sharma \& Dev Raj Sood Journal of Food Science and Technology ISSN 0022-1155 J Food Sci Technol DOI 10.1007/s13197-014-1293-y 


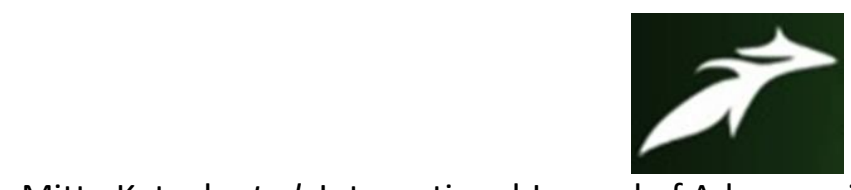

Mittu Katoch et al, International Journal of Advances in Agricultural Science and Technology, Vol.8 Issue.6, June-2021, pg. 10-26

ISSN: 2348-1358

Impact Factor: 6.057

NAAS Rating: 3.77

\section{Phenolics}

Phenolics are plant derived compounds that have many different functions, including adding colour to the plant and attracting bees and other insects for pollination (Naczk and Shahidi,2006). Many phenolics appear to have anticancer and antioxidant effects in humans (Dashwood RH, 2007) (Murphy and Hendrich, 2002) (Thomasset SC et al., 2007)

\section{Vitamins and minerals}

Vitamin E is present abundantly in flax primarily as gammatocopherol (Daun and Przybylski 2000) Flaxseed contains several water and fat-soluble vitamins (Anonymous Contractual analyses, 1997). Gamma-tocopherol is an antioxidant that protects cell proteins and fats from oxidation; promotes sodium excretion in the urine, which may help lower blood pressure; and helps lower the risk of heart disease, some types of cancer and Alzheimer disease (Morris MC et al., 2005) (Sen CK et al., 2006). The gammatocopherol content can range from 8.5 to 39.5 $\mathrm{mg} / 100 \mathrm{~g}$ of seed or about $0.7-3.2 \mathrm{mg} / \mathrm{tbsp}$ of milled flax (Daun et al., 2003) Flax contains a small amount of vitamin $\mathrm{K}$ in the form of phylloquinone, which is the plant form of the vitamin. Vitamin K plays an essential role in the formation of certain proteins involved in blood clotting and in building bone (Food and Nutrition Board, Institute of Medicine 2001, http://www.nal.usda.gov/fnic/foodcomp/Data/SR19/nutrlist/sr19a338.pdf). The mineral content of flaxseed (Anonymous Contractual analyses , 1997) is shown in Table 5. One tablespoon of milled flaxseed contains $34 \mathrm{mg}$ of magnesium, about the same amount of magnesium found in a $250 \mathrm{~mL}(8-\mathrm{oz})$ container of low-fat yogurt with fruit, $30 \mathrm{~g}(1 \mathrm{oz})$ of pecan halves, or half a fried chicken breast $(140 \mathrm{~g})$. The potassium content of milled flax is about $66 \mathrm{mg}$ per tablespoon or about the same amount of potassium found in one slice of toasted typical pumpernickel bread, a $175 \mathrm{~mL}$ (6-oz) mug of brewed tea or a hard-boiled egg (http://www.nal.usda.gov/fnic/foodcomp/Data/SR19/nutrlist/sr19a338.pdf). Flax is low in sodium. 


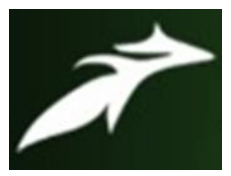

Mittu Katoch et al, International Journal of Advances in Agricultural Science and Technology, Vol.8 Issue.6, June-2021, pg. 10-26

ISSN: 2348-1358

Impact Factor: 6.057

NAAS Rating: 3.77

\section{$\underline{\text { Uses/Health Benefits }}$}

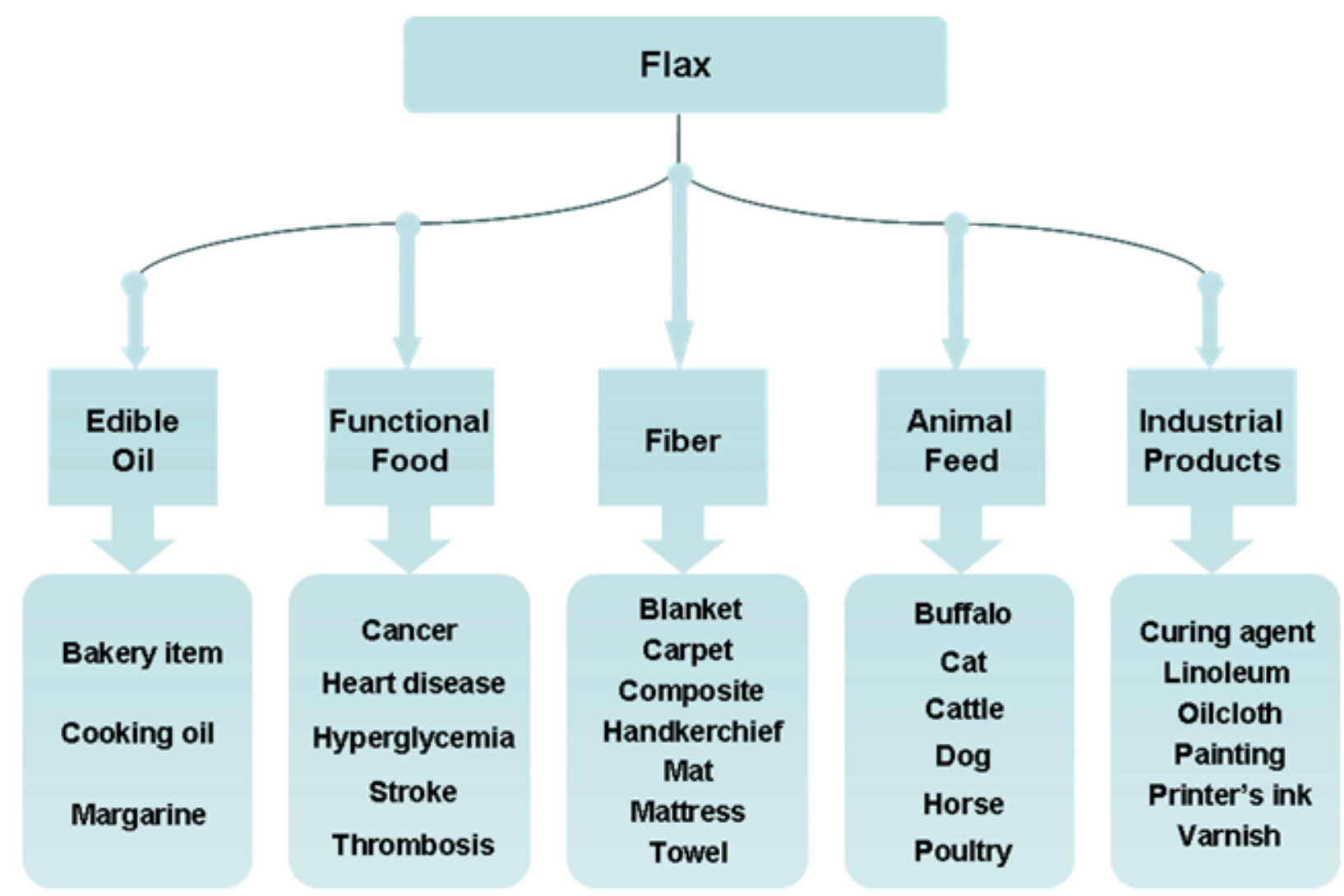

Aust. J. Basic \& Appl. Sci., 4(9): 4304-4312, 2010

\section{Flax for Human Consumption:}

Flax was being used as a food source and natural laxative dating back as far as the ancient Greeks and

Egyptians. It was also being used as a food in Asia and Africa (Berglund, D.R., 2002). The $\omega-3$ fatty acids, particularly DHA, are required for the optimal development of nervous system and maturation of visual acuity (retina) in preterm and term infants (Neuringer, M. and W.E. Connor, 1986; Uauy, R., et al., 1996). EPA and AA (arachidonic acid; C20: 4) (Bhathena, S.J., et al., 2002; Cahoon E. B., 2003; Clavel T., et al., 1991; Fitzpatrick, K., 2007)) are the precursors of eicosanoids and also components of mammalian cell membranes, including the prostaglandins, blood clotting, cell signaling and blood pressure regulation (Kinsella, J.E., et al., 1990). Deficiency in $\omega-3$ increases the chances of diabetes, cancer, arthritis, inflammatory diseases, 


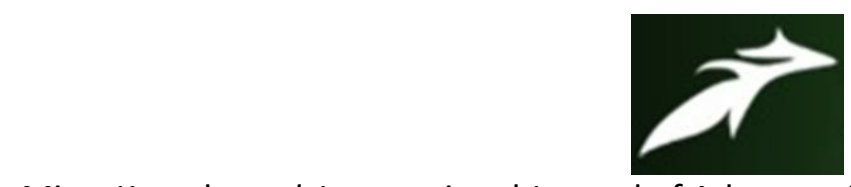

Mittu Katoch et al, International Journal of Advances in Agricultural Science and Technology, Vol.8 Issue.6, June-2021, pg. 10-26

ISSN: 2348-1358

Impact Factor: 6.057

NAAS Rating: 3.77

depression, heart disease, hypertension, memory problems, weight gain and some allergies (Morris, H.M., 2007).

\section{Flax for Edible Oil:}

The direct use of unprocessed conventional flax oil in the human diet is limited by product stability.Linseed oil with high ALA is highly susceptible to oxidation and polymerization. While these properties make it suitable for other industrial applications (discussed below), it limits the direct substitution of flax oil in placeof canola (Brassica napus) or corn (Zea mays) oil. The oil properties of flax are so unique that considerable effort is being expended to emulate the fatty acid profile. Modification of soybean oil (Glycin max) and canola oil using conventional and molecular approaches to enhance the ALA content and therefore the health benefits and to replace fish oils in the diet are an extremely active area of research ( Cahoon E.B., 2003; Scarth R. and Tang J., 2006). Edible oil of linseed also provides an opportunity to produce cocoa-butter replacement oil (Rowland, G. G., et al., 1995). However, this oil has reduced health benefits due to the reduction in $(<5 \%)$ ALA content.

\section{Flax For Functional Food:}

Functional or nutraceuticals are foods that claimed to have health-promoting or diseaseprevention properties in addition to basic nutritional properties in the food. Many health-claims have been made for whole flax seed, flax meal and milled flax. While a complete assessment of the research on flax as a functional food is beyond the scope of this article, readers are directed to (Bloedon, L.T. and P. O. Szapary, 2004; Fitzpatrick, K., 2007). A recent study in Europe indicate that the consumption of flax oil for 12 weeks (one tablespoon, providing $8 \mathrm{~g} \mathrm{ALA/day)}$ in daily diet lowered blood pressure significantly in middle aged men with high blood cholesterol levels (Paschos, G. K., et al., 2007). A role of the flax oil in preventing thrombosis has been reported in a study by $40 \%$ increase in the activated protein ratio in a population who consumed flax oil diet for six weeks (Allman-Farinelli, M.A., et al., 1999; Richard, S. and L. U. Thompson, 1997). In a study of 50 men with high blood cholesterol levels who consumed one table spoon of flax oil daily for 12 weeks reduced $48 \%$ C-reactive protein (CRP) and 32\% serum amyloid A (SAA) levels (Paschos, G.K., et al., 2005). Many studies revealed that consuming traditional milled flax or partially defatted flax decreased total cholesterol, low-density lipoprotein(LDL) cholesterol without a significant decrease in high-density lipoprotein (HDL) cholesterol (Chan, J., et al., 1991; Jenkins, D.J.A., 1999). Cardiovascular disease which includes several diseases (like coronary heart disease, stroke) is one of the leading causes of death in North America (Heart and Stroke Foundation of Canada 2003). Flax helps reduce cardiovascular diseases by altering the $\omega-3$ fatty acid content of cell membranes by improving blood lipids and endothelial function and also by exerting antioxidant effects (Bloedon, L.T. and P. O. Szapary, 2004). Flaxseed is also an important source of both soluble and insoluble fibers, which is important for the efficient digestive system. Most of the soluble fiber in flax is mucilage, which serve as an 


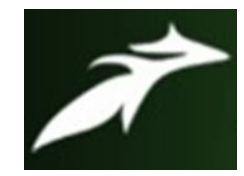

Mittu Katoch et al, International Journal of Advances in Agricultural Science and Technology, Vol.8 Issue.6, June-2021, pg. 10-26

ISSN: 2348-1358

Impact Factor: 6.057

NAAS Rating: 3.77

effective cholesterol-lowering agent. It is being utilized by backing of the flaxseed into muffins, bread or can also be added with juice. Studies have reported that insoluble fiber is also helpful in preventing constipation and regulating bowel movements. In Germany, the government has authorized use of linseed for constipation, irritable bowel syndrome and general stomach discomfort (Blumenthal, M., et al., 2000).

\section{Flax Fiber and its Uses:}

The art of weaving flax fiber to linen may have originated in Egypt because winding-clothes for the bodies of the Pharaohs of Egypt were composed of flax fiber. It was then introduced in India, where, before the use of cotton, linen was worn by many tribes (Richharia, R.H., 1962). Flax fiber is soft, lustrous and flexible. It is stronger than cotton fiber but less elastic. Fiber obtained from flax is known for its length, strength and fineness; however chemical composition and diameter are also important (Smeder, B. and S. Liljedahl, 1996). In comparison to industrial wood particles, flax particles were characterized by higher length to thickness and length to width ratios and lower bulk density (Papadopoulos, A. N. and J. R. B. Hague, 2003). The best grades are used for linen fabrics such as damasks, lace and sheeting. Coarser grades are used for the manufacturing of twine and rope. Flax fibers are also becoming an integral part of new composite materials utilized in automobile and constructive industry. Biocomposites made up from the flax fiber based on polyhydroxybutyrate (PHB) polymer could be an eco-friendly and biodegradable alternative to conventional plastics (Wrobel, M., et al., 2004). The relation between the cost of production and the comparative advantages of the fiber may limit the use of flax in large scale applications.

\section{Flax as an Animal Feed:}

Flax is integrated into animal rations in several forms; whole seed, oil supplements, hulls, or as meal. Meal, known as LSOM or linseed cake in Europe and Asia, respectively, is the residue after the extraction of oil from seeds. This valuable feed product can be used to supplement the diets of both ruminants and non-ruminants. The quantity of hull in flax seed meal is about $38 \%$, twice the level in canola or soybean meals (Agriculture and Agri-Food Canada, 1997). Flax seed oil is also used in mixed pet diets, including dogs, cats and horses. The essential fatty acids (ALA and LA) present in flax seed contribute to a lustrous coat, help prevent dry skin and dandruff, and also help in reducing digestive and skin problems in animals.

\section{Flax for Industrial Use:}

Linseed oil can also be used as "finishing oil" for wooden furniture to prevent it from denting. It does not cover the surface of wood but soaks into the pores, leaving a shiny but not glossy surface. It is used by billiards/pool cue manufacturers on the shaft portion of the cue. Linseed oil is the most important raw material used to make the flooring from linoleum. In the process of linoleum manufacturing, oxidized linseed oil is mixed with rosin and other raw material to form 


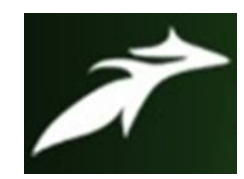

Mittu Katoch et al, International Journal of Advances in Agricultural Science and Technology, Vol.8 Issue.6, June-2021, pg. 10-26

ISSN: 2348-1358

Impact Factor: 6.057

NAAS Rating: 3.77

linoleum granules, which are pressed onto a jute backing, making linoleum sheets (Green floors linoleum flooring.Linoleum flooring. Accessed: April 23, 2008). This natural material made from a sustainable resource is long lasting and attractive.

\section{Conclusion}

Based on the information, it is evident that flaxseed is the richest source of $\alpha$-linolenic acid oil and lignans. It is a considerable potential source of high quality protein, soluble fiber, and phenolic compounds. Studies proved that flaxseed has tremendous potential in disease prevention particularly cardiovascular disease (CVD), osteoporosis, rheumatoid arthritis, cancer (breast, colon, and prostate cancer), and constipation and also affects immunity favorably. Flaxseed contains cyanogenic glycosides, linatine, and phytic acid that influence the absorption of nutrients. Processing Linum usitatissimum whole plant as renewable resource for textile fibres, valuable edible oils and various agro-fine-chemicals makes flax not only one of the foundation crops of humankind but also the "bio-economy crop" of the 21 st century. Flax seeds are now subject of sophisticated scientific and medical journals not by chance, or by fading fashion, but because of the abundance of valuable biologically active compounds included in their composition, making them worthy of being called "quintessential functional food". The pressed cake of flaxseed is one of the most valuable feeding ingredients and considered favorite for cattle feed. It is good in taste and contains $36 \%$ protein with $85 \%$ digestibility. Feeding omega-3 enriched diets to poultry increases the omega- 3 content in eggs and meat and thus enriches poultry products. Flax fiber is biodegradable and composite, which exhibit good mechanical properties and low density. The flaxseed has tremendous potential to be used as human food, animal feed, and good quality fiber.

\section{References}

1. Agriculture and Agri-Food Canada, 1997. Flaxseed: Situation and outlook, bi-weekly bulletin, Market.

2. Allman-Farinelli, M.A., D. Hall, K. Kingham, D. Pang, P. Petocz and E.J. Favaloro, 1999. Comparison of the effects of two low fat diets with different $\alpha$-linolenic:linoleic acid ratios on coagulation and fibrinolysis. Atherosclerosis, 142(1): 159-168.

3. Anonymous Contractual analyses (1997) Flax Council of Canada, Winnipeg, MB.

4. Analysis Division, Policy Branch, Agriculture and Agri-Food Canada, 10: 22, Winnipeg, MB.

5. Aubrecht E, Horacsek M, Gelencser E, Dworschak E (1998) Investigation of prolamin content of cereals and different plant seeds. Acta Alimentaria 27: 119-125.

6. BeMiller JN, Whistler RL, Barkalow DG, Chen CC (1993) Aloe, Chia, Flaxseed, Okra, Psyllium Seed, Quince Seed, and Tamarind Gums. Industrial Gums (3rdedn), Academic Press, USA. 


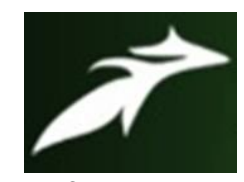

Mittu Katoch et al, International Journal of Advances in Agricultural Science and Technology, Vol.8 Issue.6, June-2021, pg. 10-26

ISSN: 2348-1358

Impact Factor: 6.057

NAAS Rating: 3.77

7. Berglund, D.R., 2002. Flax: New uses and demands. In: Janick,J. and A. Whipkey (eds.), Trends in New Crops and New Uses. ASHS Press, Alexandria, VA, USA, pp: 358-360.

8. Bhathena, S.J., A.A. Ali, A.I. Mohamed, C.T. Hansen and M.T. Velasquez, 2002. Differential effects of dietary flaxseed protein and soy protein on plasma triglyceride and uric acid levels in animal models. J. Nutr. Biochem., 13(11): 684-689.

9. Bhatty RS. Nutritional composition of whole flaxseed and flaxseed meal. Flaxseed in HumanNutrition. Cunnane SC, Thompson LH, editors. AOCS Press, Champaign IL. 1995; 22-45.

10. Bloedon, L.T. and P.O. Szapary, 2004. Flaxseed and cardiovascular risk. Nutr. Rev., 62: 18-27.

11. Blumenthal, M., A. Goldberg and J. Brinckmann (eds), 2000, Herbal Medicine: Expanded Commission E. Monographs, American Botanical Council, Austin, TX, USA, pp: 85.

12. Cahoon, E.B., 2003. Genetic enhancement of soybean oil for industrial uses: Prospects and challenges. AgBioForum, 6: 11-13.

13. Chan, J., V. Bruce and B. McDonald, 1991. Dietary alpha-linolenic acid is as effective as oleic acid and linoleic acid in lowering blood cholesterol in normolipidemic men. Am. J. Clin. Nutr., 53(5): 1230-1234.

14. Chan, J.K., McDonald, B.E., Gerrad, J.M., Bruce, V.M., Weaver, B. J. and Holub, B.J. 1993. Effect of dietary alpha-linolenic acid and its ratio to linoleic acid on platelet and plasma fatty acids and thrombogenesis. Lipids 28 (9): 811-817.

15. Clavel, T., D. Borrmann, A. Braune, J. Dore and M. Blaut, 1991. Occurrence and activity of human intestinal bacteria involved in the conversion of dietary lignans. Am. J. Clin. Nutr., 53: 1230-1234.

16. Cui, W., Mazza, G. and Biliaderis, C.G. 1994. Chemical structure, molecular size distributions and rheological properties of flaxseed gum. Journal of Agricultural and Food Chemistry 42 (9): 1891-1895.

17. Das UN (2006) Essential Fatty acids - a review. Curr Pharm Biotechnol 7: 467-482.

18. Dashwood RH (2007) Frontiers in polyphenols and cancer prevention. J Nutr 137: 267S269S.

19. Daun JK, DeClercq DR (1994) Sixty years of Canadian flaxseed quality surveys at the Grain Research Laboratory. Proc Flax Inst 55: 192-200.

20. Daun JK, Przybylski R (2000) Environmental effects on the composition of four Canadian flax cultivars. Proc Flax Inst 58: 80-91.

21. Daun JK, Barthet VJ, Chornick TL, Duguid S (2003) Structure, Composition, and Variety Development of Flaxseed. Flaxseed in Human Nutrition (2ndEdn), AOCS Press, USA. 


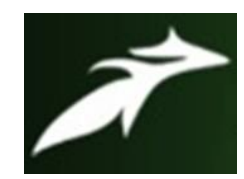

Mittu Katoch et al, International Journal of Advances in Agricultural Science and Technology, Vol.8 Issue.6, June-2021, pg. 10-26

ISSN: 2348-1358

Impact Factor: 6.057

NAAS Rating: 3.77

22. Diederichsen, A. and Richards, K. 2003. Cultivated flax and the genus Linnum L.: taxonomy and gerplasm conservation. In Muir, A. D. and Westcott, N. D. (Eds). Flax, The genus Linum, p. 22-54. London: Taylor \& Francis.

23. de Lorgeril M, Salen P, Laporte F, de Leiris J. 2001. Alpha-linolenic acid in the prevention and treatment of coronary heart disease. Eur Heart J Suppl D 3:D26-D32 (2001) Nutritional profile of no. 1 Canada Western flaxseed and of yellow flaxseed samples. Canadian Grain Commission, Winnipeg, MB. http://botanical.com/botanical/mgmh/mgmh.html

24. Doyon M, Labrecque J. Functional foods: a conceptual definition. British Food Journal. 2008; 110: 1133- 1149.

25. Eastwood, M.A. and Passmore, R. 1983. Dietary fiber. The Lancet. 2 (8343): 202-206.

26. Fedenuik RW, Biliaderis CG (1994) Composition and physiochemical properties of linseed (Linum usitatissimum) mucilage. J Agric Food Chem 42:240-247

27. Fitzpatrick, K., 2007. Innovation in western Canadian functional food. Cereal Foods World, 52: 289-290.

28. Food and Nutrition Board, Institute of Medicine (2001) Dietary Reference Intakes for Vitamin A, Vitamin K, Arsenic, Boron, Chromium, Copper, Iodine, Iron, Manganese, Molybdenum, Nickel, Silicon, Vanadium, and Zinc. The National Academies Press, Washington, DC, USA. http://www.nal.usda.gov/fnic/foodcomp/Data/SR19/nutrlist/sr19a338.pdf

29. Gopalan C, Sastri R, Balasubramanian SC (2004) Nutritive value of Indian foods. National Institute of Nutrition, ICMR, Hyderabad,52 pp

30. Green, A.G. and D.R. Marshall, 1984. Isolation of induced mutants in linseed (Linum usitatissimum L.) having reduced linolenic acid content. Euphytica, 33: 321-328.

31. Hall, C. and Shultz, K. 2001. Phenolic antioxidant interactions. In Abstracts of the 92nd American Oil Chemists Society Annual Meeting and Expo. p. S88 Minneapolis, Minnesota: AOCS

32. Heart and Stroke Foundation of Canada, 2003. The growing burden of heart disease and stroke in Canada 2003. Accessed: May 14, 2008. http://ww2.heartandstroke.ca/Page.asp?PageID=1613\&ContentID=10564\& ContentTypeID $=1$.

33. Hosseinian FS, Beta T (2009) Patented techniques for the extraction and isolation of secoisolariciresinol diglucoside from flaxseed. Recent Patents Food Nutr Agric 25:25-31

34. Huang, S., D. Milles, 1996. Gamma-linolenic acid: Metabolism and its roles in nutrition and medicine. Champaign, IL, AOCS Press.

35. Huang, S., A. Ziboh, 2001. Gamma-linolenic acid: Recent advances in biotechnology and clinical applications. Champaign, IL, AOCS Press.

36. Hurteau, M.C. 2004. Unique new food products contain good omega fats. Journal of Food Science Education 3 (4): 52-53. 


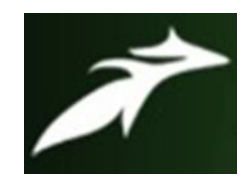

Mittu Katoch et al, International Journal of Advances in Agricultural Science and Technology, Vol.8 Issue.6, June-2021, pg. 10-26

ISSN: 2348-1358

Impact Factor: 6.057

NAAS Rating: 3.77

37. (Institute of Medicine (2002) Dietary Reference Intakes for Energy, Carbohydrate, Fiber, Fat, Fatty Acids, Cholesterol, Protein, and Amino Acids (Macronutrients). National Academies Press, Washington, DC, USA.)

38. Jenkins, D.J.A., C.W.C. Kendall, E. Vidgen, S. Agarwal, A.V. Rao and R.S. Rosenberg, 1999. Health aspects of partially defatted flaxseed, including effects on serum lipids, oxidative measures, and ex vivo androgen and progestin activity: a controlled crossover trial. Am. J. Clin. Nutr., 69(3): 395-402.

39. Kalra EK. Nutraceutical--definition and introduction. See comment in PubMed Commons below AAPS PharmSci. 2003; 5: E25.

40. Kamal-Eldin A, Peerlkamp N, Johnsson P, Andersson R, Andersson RE, Lundgren LN, Aman P (2001) An oligomer from flaxseed composed of secoisolariciresinol diglucoside and 3-hydroxy-3-methyl glutaric acid residues. Photochemistry 58:587-590

41. Kinsella, J.E., B. Lokesh, S. Broughton and J. Whelan, 1990. Dietary polyunsaturated fatty acids and eicosanoids: Potential effects on the modulation of inflammatory and immune cells: An overview. Nutrition, 6: 24-44.

42. Madusudhan, K.T. and Singh, N. 1983. Studies on linseed proteins. Journal of Agricultural and Food Chemistry 31 (5): 959-963.

43. Meagher, L.P., Beecher, G.R., Flanagan, V.P. and Li, B.W. 1999. Isolation and characterization of the lignans, isolariciresinol and pinoresinol, in flaxseed meal. Journal of Agricultural Food Chemistry 47 (8): 3173-3180.

44. Meagher LP, Beecher GR (2000)Assessment of data on the lignin content of foods. J Food Comp Anal 13:935-947

45. Mazza G, Biliaderis CG (1989) Functional properties of flaxseed mucilage. J Food Sci 54:1302-1307

46. Mazur W, Uehara M, Wahala K, Adlercreutz H (2000) Phytoestrogen content of berries, and plasma concentrations and urinary excretion of enterolactone after a single strawberry-meal in human subjects.Br J Nutr 83:381-387

47. Morris, D.H. 2003. Flax: A health and nutrition primer. 3rd ed, p.11 Winnipeg: Flax Council of Canada. Downloaded from http://www.jitinc.com/flax/brochure02.pdf verified on $4 / 6 / 12$

48. Morris, D.H. 2004. Other health benefits of flax. In Flax: A Health and Nutrition Primer, Flax Council of Canada. Downloaded from http:www.flaxcouncil.ca/english/pdf/FlxPrmr_4ed_Chpt7.pdf on 4/6/2012

49. Morris MC, Evans DA, Tangney CC, Bienias JL, Wilson RS, et al. (2005) Relation of the tocopherol forms to incident Alzheimer disease and to cognitive change. Am J Clin Nutr 81: 508-514.

50. Morris DH. Flax Primer, A Health and Nutrition Primer. Flax Council of Canada. 2007; 9-19. 


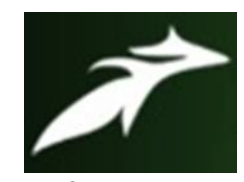

Mittu Katoch et al, International Journal of Advances in Agricultural Science and Technology, Vol.8 Issue.6, June-2021, pg. 10-26

ISSN: 2348-1358

Impact Factor: 6.057

NAAS Rating: 3.77

51. Muir AD (2006) Flax lignans - analytical methods and how they influence our understanding of biological activity. J AOAC Int 89:1147- 1157

52. Murphy PA, Hendrich S (2002) Phytoestrogens in foods. Adv Food Nutr Res 44: 195246.

53. Naczk M, Shahidi F (2006) Phenolics in cereals, fruits and vegetables: occurrence, extraction and analysis. J Pharm Biomed Anal 41: 1523-1542.)

54. Neuringer, M. and W.E. Connor, 1986. n-3 fatty acids in the brain and retina: evidence for their essentiality. Nutr. Rev., 44: 285-294.

55. Oomah BD, Mazza G (1993) Flaxseed proteins—a review. Food Chem 48:109-114

56. Oomah, B.D. and Mazza, G. 1995. Functional properties and uses of flaxseed protein. Inform 6 (11): 1246-1252.

57. Oomah, B.D. and Mazza, G. 1997. Effect of dehulling on chemical composition and physical properties of flaxseed. Lebensmittel-Wissenschaft und-Technologie 30 (2): 135140.

58. Oomah, B.D. and Mazza, G. 1998. Flaxseed products for disease prevention. In Mazza, G. (Ed). Functional Foods: Biochemical and Processing Aspects. p. 91-138. Lancaster, PA: Technomic Publication Company Inc.

59. Oomah BD(2001) Flaxseed as a functional food source. J Sci FoodAgric 81:889-894

60. Papadopoulos, A.N. and J.R.B. Hague, 2003. The potential for using flax (Linum usitatissimum L.) shiv as a lignocellulosic raw material for particleboard. Ind. Crop Prod., 17: 143-147.

61. Paschos, G.K., N. Yiannakouris, L.S. Rallidis, I. Davies and B.A. Griffin, 2005. Apolipoprotein $\mathrm{E}$ genotype in dyslipidemic patients and response of blood lipids and inflammatory markers to alpha-linolenic acid. Angiology, 56: 49-60.

62. Paschos, G.K., F. Magkos, D.B. Panagiotakos, V. Votteas and A. Zampelas, 2007. Dietary supplementation with flaxseed oil lowers blood pressure in dyslipidaemic patients. Eur. J. Clin. Nutr., 61: 1201-1206.

63. Payne TJ (2000) Promoting better health with flaxseed in bread. Cereal Foods World 45(3):102-104

64. Pradhan R, Meda V, Rout P, Naik S (2010) Supercritical CO2 extraction processes. J Food Eng 98: 393-397.

65. Raffaelli B, Hoikkala A, Leppala E, Wahala K (2002) Enterolignans. J Chromatogr 777:29-43.

66. Richard, S. and L.U. Thompson, 1997. Health effects of flaxseed mucilage, lignans. International News on Fats, Oils and Related Materials (INF), 8: 860-865.

67. Richharia, R.H., 1962. Linseed. The Indian Central Oiseeds Committee, Hyderabad, India, pp. 155. 


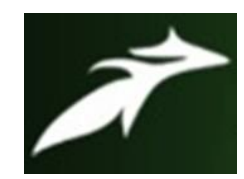

Mittu Katoch et al, International Journal of Advances in Agricultural Science and Technology, Vol.8 Issue.6, June-2021, pg. 10-26

ISSN: 2348-1358

Impact Factor: 6.057

NAAS Rating: 3.77

68. Riediger ND, Othman R, Fitz E, Pierce GN, Suh M, Moghadasian MH (2009) Low n6:n3 fatty acid ratio, with fish or flaxseed oil, in high fat diet improves plasma lipids and beneficially alters tissue fatty acid composition in mice. Eur J Nutr 47:153-160

69. Rowland, G.G., A. McHughen, R.S. Bhatty, S.L. Mackenzie and D.C. Taylor, 1995. The application of chemical mutagenesis and biotechnology to the modification of linseed (Linum usitatissimum L.). Euphytica, 85(1-3): 317-321.

70. Safe S, Papineni S (2006) The role of xenoestrogenic compounds in the development of breast cancer. Trends Pharmacol Sci 27: 447-454.)

71. Scarth R. and J. Tang, 2006. Modification of Brassica oil using conventional and transgenic approaches.Crop Sci., 46: 1225-1236.

72. Sen CK, Khanna S, Roy S (2006) Tocotrienols: Vitamin E beyond tocopherols. Life Sci 78: 2088-2098.

73. Simopoulos, A. P., 2002. The importance of the ratio of omega-6/ omega-3 essential fatty acids. Biomedicine and Pharmacotheraphy, 56, 365-379.

74. Smeder, B. and S. Liljedahl, 1996. Market oriented identification of important properties in developing flax fibers for technical uses. Ind. Crop Prod., 5: 149-162.

75. Susheelamma NS (1987) Isolation and properties of linseed mucilage. J Food Sci Technol 24:103-106

76. Tarpila A, Wennberg T, Tarpila S (2005) Flaxseed as a functional food. Curr Top Nutraceutical Res 3:167-188

77. Thomasset SC, Berry DP, Garcea G, Marczylo T, Steward WP, et al. (2007) Dietary polyphenolic phytochemicals--promising cancer chemopreventive agents in humans? A review of their clinical properties. Int J Cancer 120: 451- 458.

78. Thompson, L.U., Robb, P., Serraino, M. and Cheung, F. 1991. Mammalian lignan production from various foods. Nutrition and Cancer 16 (1): 43-52.

79. Toure A, Xueming X (2010) Flaxseed lignans: source, biosynthesis, metabolism, antioxidant activity, bio-active components and health benefits. Compr Rev Food Sci Food Saf 9:261-269

80. Uauy, R., P. Perano, D. Hoffman, P. Mena, D. Birch and E. Birch, 1996. Role of essential fatty acids in the function of the developing nervous system. Lipids, Suppl.: S167-S176

81. Vaisey-Genser, M. and Morris, D.H. 2003. Introduction: history of the cultivation and uses of flaxseed. In Muir, A. D. and Westcott, N. D. (Eds). Flax: The genus Linum. p. 12. London: Taylor \& Francis

82. Wanasundara JP, Shahidi F (1994) Functional properties and amino acid composition of solvent extracted flaxseeds meals. Food Chem 49: 45-51

83. Wanasundara PKJPD, Shahidi F (1997) Removal of flaxseed mucilage by chemical and enzymatic treatments. Food Chem 59:47-55 


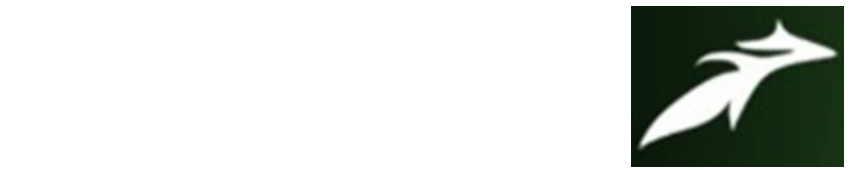

Mittu Katoch et al, International Journal of Advances in Agricultural Science and Technology, Vol.8 Issue.6, June-2021, pg. 10-26

ISSN: 2348-1358 Impact Factor: 6.057 NAAS Rating: 3.77

84. Warrand J, Michaud P, Picton L, Muller G, Courtois B, et al. (2005) Contributions of intermolecular interactions between constitutive arabinoxylans to the flaxseeds mucilage properties. Biomacromolecules 6: 1871-1876.)

85. Wrobel, M., J. Zebrowski and J. Szopa, 2004. Polyhydroxybutyrate synthesis in transgenic flax. J. Biotech., 107: 41-54. 